\title{
ASPECTS OF ECONOMIC PRODUCTION IN MALAY CLASSICAL LITERATURE ACCORDING TO SHEIKH DAUD AL-FATANI
}

\author{
Hadenan Towpek \& Joni Tamkin Borhan \\ Academy of Islamic Studies, University of Malaya Kuala Lumpur Malaysia
}

\begin{abstract}
Sheikh Daud bin 'Abdullah al-Fatani (1131-1265AH/1718-1847CE) is a Malay scholar who appears on the transition period to $18 \mathrm{M}$ and $19 \mathrm{M}$ century. He was known as a productive scholar and prolific book, which can be viewed from various aspects. Therefore, this article attempts to analyze his views on aspects of production as discussed in his masterpiece Furu'al-Masa'il and specifically referred to in chapter transaction. This article uses content analysis methods through a thematic approach in identifying the aspects of production. This article identifies at least nine aspects contained in the production of the work of priority in economic aspect, the aspect of work/effort, capital, profit-generating aspect, the aspect of profit distribution, aspects of joint agricultural projects, exploring aspects of soil, aspect prohibition of usury and aspects of the general offer. This finding indirectly indicates that the views of Sheikh Daud al-Fatani presented in the book furu' al-Masa'il are an ever green that is a deep insight into and remain relevant from the past, present and future.
\end{abstract}

Key Words: Economic, Production, Malay, Daud Al-Fatani

\section{INTRODUCTION}

With maturity of knowledge and spirit expand into the global Muslim community, especially the Malays, Sheikh Daud al-Fatani has produced the book Furu' al-Masa'il regarded as a complete work that includes aspects of worship, jurisprudence, marriage, crime and other aspects. As such this book is regarded as the top work in the field of jurisprudence in the archipelago of the $19^{\text {th }}$ century. ${ }^{1}$ Accordingly, this article present a scientific analysis using content analysis of his views on the economic concepts as discussed in his Furu' al-Masa'il. Prior to that, this article first introduces briefly the biodata of the author and the background of the book.

1 Abdul Rahman Haji Abdullah. 1990. Pemikiran Umat Islam di Nusantara: Sejarah dan Perkembangannya Hingga Abad Ke-19. Kuala Lumpur: Dewan Bahasa dan Pustaka, p. 138. 


\section{SHEIKH DAUD AL-FATANI AND THE BOOK OF FURU` $A L-M A S A^{\prime} I L$}

His full name is Sheikh Wan Daud bin Sheikh Wan Abdullah bin Sheikh Wan Idris@ Tok Wan Derasid @ Sheikh Wan Senik bin Tok Wan Abu Bakr bin Tok Kaya Pandak bin Andi (Faqih) Ali Datuk Maharajalela. He is better known as "Tok Sheikh Daud Fatani". He also received other titles such as "al'Alim al-'Allamah al-'Arif al-Rabbani", "Sheikh Daud Waliullah", "Sheikh Daud Keramat" and "Sheikh Daud The Author".

He was born in the village Kerisik ${ }^{3}$ in Pattani Province of Thailand, around the year $1131 \mathrm{AH} / 1718 \mathrm{CE} .{ }^{4}$ He received his early education from his own family, from father and grandfather, and the opportunity to study under the local scholars who come from the Middle East or Yemen. Later, he also said to have learned in Aceh for two years before he went to the Hijaz. He studied in Mecca for 30 years and in Medina for 5 years. ${ }^{5} \mathrm{He}$ died and was buried in Ta'if in 1265AH/1847CE. ${ }^{6}$

While this book, the full title is Furu' al-Masa'il wa Usul al-Wasa'il, resulting in $1254 \mathrm{AH} / 1838 \mathrm{CE}$ and settled at $1257 \mathrm{AH} / 1841 \mathrm{CE} .^{7}$ This book is his greatest work in the fields of law and Islamic thought has ever found in Mecca since the 1880s. ${ }^{8}$ In English, Furu' al-Masa'il translated as "branches of religious issues". At present, the printed version of the book is still repeated-print, available on the market and used in traditional institutions, especially in Peninsular Malaysia and Thailand Pattani Province, ${ }^{10}$ is the printed version of Matba'ah Bin Halabi, Pattani Thailand using the printed version of Matba'ah Dar Ihya'

2 Wan Mohd. Shaghir Abdullah. 1990. Syeikh Daud bin Abdullah al-Fatani: Ulama dan Pengarang Terulung Asia Tenggara. Shah Alam: HIZBI, p. 21-22; Idem. 1991a. Sejarah Rengkas Syeikh Daud bin Abdullah al-Fatani dan Karya-karyanya. Nadwah Ilmiah Tokoh Ulama Peringkat Kebangsaan Kali Keempat. (The Islamic Affairs Division, Prime Minister Department in collaboration with Islamic Academy of University of Malaya Kuala Lumpur, 17-19 Dicember), p. 18; Hooker, M.B. 1991. Undang-undang Islam di Asia Tenggara. Kuala Lumpur: Dewan Bahasa dan Pustaka, p. 73.

3 Wan Mohd. Shaghir. 1990. op. cit., p. 20; Idem. 1991a. op. cit., p. 8.

4 Wan Mohd. Shaghir. 1990. op. cit., p. 4-7; Idem. 2003. Mun-yatul Mushalli Syeikh Daud al-Fathani: Pengetahuan Sembahyang Masyhur. Kuala Lumpur: Khazanah Fathaniyah, p. 7.

5 Wan Mohd. Shaghir. 1990. op. cit., p. 24-25.

6 Wan Mohd. Shaghir. 1991a. op. cit., p. 5.

7 Wan Mohd. Shaghir. 2003. op. cit., p. 20.

8 Matheson, V. \& Hooker, M.B. 1988. Jawi Literature in Patani: the Maintenance of an Islamic Tradition. JMBRAS, Vol. 61, Part 1, p. 22.

9 Mohamad @ Md. Som Sujimon \& Wan Sabri bin Wan Yusoff. 2003. Sheikh Da'ud al-Fatani's Contribution to Muslim Scholarship in Malaysia. Monograph on Selected Malay Intellectuals. Kuala Lumpur: Research Centre IIUM, p. 33.

10 Hadenan bin Towpek. 2010. Beberapa Sumbangan Syeikh Daud al-Fatani Dalam Sistem Pengajian Pondok di Kelantan. Seminar Keintelektualan Islam, (The Centre for Islamic Thought and Understanding, UiTM Kelantan Branch, in collaboration with the Kelantan Federal Development Department, 31 May-1 June), p. 3 \& 8. 
al-Kutub al-'Arabiyyah, Egypt. ${ }^{11}$

In terms of knowledge, Syeikh Daud al-Fatani as deemed by Azyumardi Azra as a scholar who has more than enough knowledge to make him appear as a major scholar in the Malay-Indonesian transition period $18^{\text {th }}$ and $19^{\text {th }}$ centuries. ${ }^{12}$ For western scholars such as M.B. Hooker, it is concluded that the knowledge and leadership qualities that he possessed has not been matched by Islamic scholars of his time and the time thereafter until now. ${ }^{13}$ While studies carried out by Wan Mohd. Shaghir found that he was a prolific scholar who wrote 69 book titles of works of various fields which can be identified, namely monotheism (13 titles), fiqh (22 titles), Sufism (13 titles), history (8 titles) and other areas (13 title). ${ }^{14}$

In this article, the corpus study of the book Furu' al-Masa'il is based on the printed version of Matbaah Bin Halabi, Patani, Thailand, with two volumes of 275p. (Volume 1), 393p. (Volume 2), with 35 lines on each page, with the sides printed book known as Kasyf al-Ghummah, another Sheih Daud works as well.

\section{SCOPE OF DISCUSSION}

In the hierarchy of goods and services, is the first stage of production prior to marketing (distribution) and consumption. The production of goods is solely for the purpose of consumption. Production levels tied to the needs and wants in consumption. Therefore, this article focuses on aspects of production will be identified in the discussion of Islamic jurisprudence in the chapter by referring to the muamalat book written in jawi in Sheikh Daud's classical masterpiece of the book Furu' al-Masa'il.

To achieved this target, this article applies basically three stages of making the book Furu' al-Masa'il Sheikh Daud al-Fatani masterpiece as the main input, especially in muamalat chapter; then stage process based approach to content analysis focuses on the production aspects as basic economic function, and based on thematic approach, and finally its produce output in term of aspects of production according to Sheikh Daud al-Fatani. This three stages of studies can easily illustrated by diagram below:

11 Daud bin 'Abdullah al-Fatani, Furu' al-Masa'il, V. 2. Patani: Matba'ah Bin Halabi, p. 389.

12 Azyumardi Azra. 1995. Jaringan Ulama Timur Tengah dan Kepulauan Nusantara Abad XVII dan XVIII: Melacak Akar-akar Pembaharuan Pemikiran Islam di Indonesia. Bandung, Indonesia: Penerbit Mizan, p. 266.

13 Hooker, M.B. (ed.). 1986. The Laws of South-east Asia (Vol. I: The-Modern Texts). Singapore: Butterworth \& Co (Asia) Pte Ltd, p. 363.

14 Wan Mohd. Shaghir. 1991a., op. cit., p. 21; Idem. 1995. Manuskrip Islam Dunia Melayu Ditinjau Dari Pelbagai Peringkat. Intellectual Forum. (The Department of Malay Studies, University of Malaya), p. 9; Idem. 2003. op. cit., p. 15-16. 


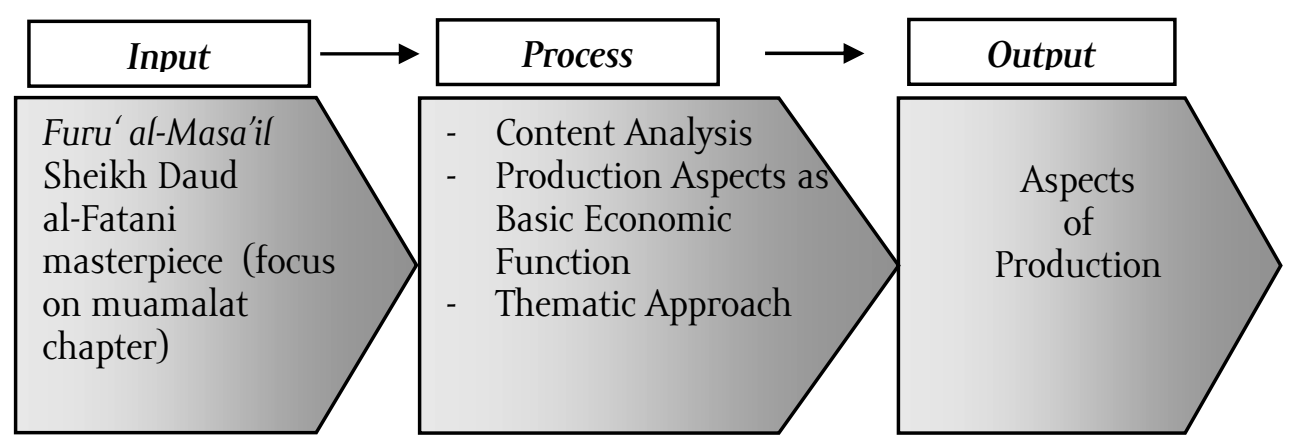

\section{ANALYSIS ON ASPECTS OF PRODUCTION}

Aspects of production can be identified within the corpus of the study are as follows:

\section{Aspect of Priority in Economic}

In most cases the priority in economic concept can be associated with an economy that makes the community faced with a scarcity, which is the state of an economy that has limited economic resources compared with unlimited needs among members of society. It gives a element of choice of the need which must be met first, and think about how limited resources can be allocated to the various consumptions that compete with each other. As such, it raises the opportunity cost aspect which is the activities or goods that had the second best alternative is reduced to allow the community to acquire the goods required. ${ }^{15}$

The above phenomena can be linked indirectly to the discussion Sheikh Daud al-Fatani of economic activities should be prioritized to meet the norms of society. In this case, he argues that economic activity should be given priority is agriculture, followed by wood artisan activities or take wages, and follow by business activities. ${ }^{16}$

Priorities chart for economic activity according to Sheikh Daud al-Fatani this implies that his views confirmed that element of scarcity brings consequent to element of choice for economic activities that should be given priority, and at the meantime also raises the opportunity cost where the second most important activity which is wood artisan activities or take wages have to reduce in order to give preferences to agricultural activities.

15 Lihat: Jomo K.S. \& Ishak Shari. 2003. Mikroekonomi. Kuala Lumpur: Utusan Publications \& Distributors, p. 26-27.

16 Daud bin Abdullah al-Fatani, op. cit., p. 3. 


\section{Aspects of Work / Effort}

In conventional economics, work / effort is considered as one of the production factors. In this corpus study, work / effort especially when expressed directly mentioned types of work, such as farming, trade, taking wages, money changers, and others.

In addition, aspects of work/effort can also be specifically identified in the discussion of mudarabah. In this regard, Sheikh Daud al-Fatani explained that the conditions for work or job specifications shall be of the type of skills required for entrepreneurs, not the type of activity is prohibited, without the binding conditions of the transaction, and free of the delay element in terms of time and particular conditions. ${ }^{17}$

Description of the job / work specification in the mudarabah contract can be used as a guide in the application of joint venture financing contracts involving the capital owners from among the surplus sector in the economy with entrepreneurs who need capital to do business or work in business projects, trading, manufacturing and construction.

\section{Aspect of Capital}

Aspect of capital is one of the factors of production in the economic system. In this case, the discussion in the corpus of research on capital aspects associated with business contracts, particularly contracts of bay'al-salam, mudarabah and musharakah. According to Sheikh Daud al-Fatani, the capital in the contract in bay' al-salam has some specific features, among which are submitted at the time of the contract, the type of property or services, and the form of property either aqar or manqul. ${ }^{18}$

In mudarabah contract, according to Sheikh Daud al-Fatani, an asset or capital of mudarabah should be of the type property of silver (gold) or dinar (silver), known rate, type and characteristics, the particular property, and can be delivered. ${ }^{19}$

While capital of musharakah, Sheikh Daud al-Fatani in Furu' al-Masa'il discuss the specific conditions on the types of property are allowed to be contracted as musharakah based. Such conditions can be summarized as follows: type currency is genuine, there is mixing of two properties to not be differentiated, and the same kind of property. ${ }^{20}$

17 Ibid., p. 108.

18 Ibid., p. 39-43.

19 Ibid., p. 107-108.

20 Ibid., p. 76. 


\section{Aspect of Profit Generated}

Further scrutiny in corpus studies can also describe aspects of profit particularly in terms of generating profits directly discussed in the topic of musharakah and mudarabah contracts.

For the contract of musharakah, Sheikh Daud al-Fatani emphasizes the profit generation with element of consent to business partner to deal in musharakah properties. Elements of this consent subject to the scope that do not harm, including maintaining ceiling price in the absence of market response, but a better price when the market response. In addition, the element of consent also includes selecting a lot more value in the event khiyar, the transaction cannot be done with grace price, or not cost the state, or the price of a large loss and merchandise cannot be sent on traveling, or submitted to any other parties for the transaction. ${ }^{21}$

Similarly, in the mudarabah contract where Sheikh Daud al-Fatani explained that generating profits is one of the key elements of the mudarabah contract. Therefore, entrepreneur responsible for ensuring that mudarabah business can generate profits, including selling with a profit and avoid severe losses; not be sold on a deferred basis without the consent of capital owner; be sold in exchange even without the consent of capital owner; not ban activities in mudarabah contract; zawa'id property is belong to capital owner; and profits will be used to cover the depreciation of mudarabah property. ${ }^{22}$

\section{Aspect of Profit Distribution}

Basically the price aspect is included in the pillars of business. A reasonable price level is necessary to generate profits and ultimately be distributed among the entrepreneurs and investors in the mudarabah financing contract. According to Sheikh Daud al-Fatani, one of the pillars of mudarabah contract is the distribution of profits to the conditions as distributed between capital owners and entrepreneurs cannot be handed over to one side, and certain methods of distribution. ${ }^{23}$

Besides mudarabah contract, musharakah contracts also have a bearing on price and profitability aspects, especially in determining the distribution of profits. In Furu' al-Masa'il explained that the allocation of profit and loss in musharakah contract is on the contribution ratio of their own property. If the contribution rate is the same, then the division rate is the same as well. If one party contributes a hundred and the other contributes fifty, then the ratio was one-third. ${ }^{24}$

21 Ibid., p. 76-77.

22 Ibid., p. 109-110.

23 Ibid., p. 108-109.

24 Ibid., p. 77. 


\section{Aspect of Joint Venture in Agriculture Project}

Aspects of joint venture in agricultural projects normally associated with the three link contracts, which are musaqah, muzara'ah and mukhabarah. All three contracts are interrelated with land resource as a function of production. In this regard, Sheikh Daud al-Fatani discusses the three contracts under subheading namely bab al-musaqah, with all three like that this contract is a form of agriculture financing project with certain conditions. Musaqah contract is allowable only, while muzara'ah and mukhabarah is not allowed because it involves element of uncertainty which the reward is in the form of the crop when it does not exist and there is no guarantee for it arises.

However, it is permissible if the muzara'a h contract in accordance with contract musaqah, and both of these contracts cannot be separated for agricultural projects involving irrigation works and the anointing of water on the crops. Thus, if irrigation works and the anointing were not done causing damaged crops, and then the employee must bear the liabilities. ${ }^{25}$

\section{Aspect of Land Exploration}

Land as one of the factors of production is essentially a must to develop as understood through the contract ihya' al-mawat. The treasury of the Islamic jurisprudence, a land not yet owned and has not worked is known as the land of the dead. Therefore, it should be explored through activities or employment to working such as agriculture.

In this regard, Sheikh Daud al-Fatani in the corpus of this article also explains that circumcision to revive a dead land-based understanding of the meaning of the hadith: "Whoever revives the earth to die for him and reward him claiming the goods consumed by the provision of charity". ${ }^{26}$ The action included in reviving the land of the dead is by making it as a burial ground. ${ }^{27}$

\section{Aspect of Usury}

In the conventional economic system, factors of production for capital income are based on usury. The higher the usury rate charged on the capital factor, the higher the savings income. However, on behalf of entrepreneur or businessmen, higher usury rate affects the demand for capital decreases.

In this regard, Sheikh Daud al-Fatani explained about the illegal prohibition of usury practices and transactions in daily activities, whether it is called riba al-fadl or riba al-nasiah because it brings injustice to the parties involved. Riba al-nasiah occurred in the practice of borrowing money paid more than 
the principal amount, while riba al-fadl occurs in a transaction consisting of six types of commodities from gold, silver, wheat, barley, dates and that when the exchange tamathul with the same type must taqabud (with the same measurement or weight) and hulul (cash in the contract). 'Illah given is that because gold and silver is the currency and the next four are the main food commodities. $^{28}$

\section{Aspects of the General Offer}

Aspects of the general offer by one party offering a reward, usually in the form of financing with a certain amount to anyone who can perform or meet the demands of the party offering it, within what is permitted by Islamic law.

Aspects of this public offering may be associated with the ju'alah contract as discussed by Sheikh Daud al-Fatani in Furu' al-Masa'il in transaction chapter. In the contemporary context, this aspect is applied, such as RM1000 reward to find missing cat, the reward of RM1 million to obtain evidence of the case, the reward of RM50,000 to anyone who provides information to the authorities about a criminal case, and the like.

\section{CONCLUSION}

This writing is an effort to deal with the thoughts of classical Malay scholar such as Sheikh Daud al-Fatani, through scrutiny of the work of the Jawi book which is Furu' al-Masa'il. This writing identify nine aspects of production to discussed indirectly in the work as outlined in the following diagram below:

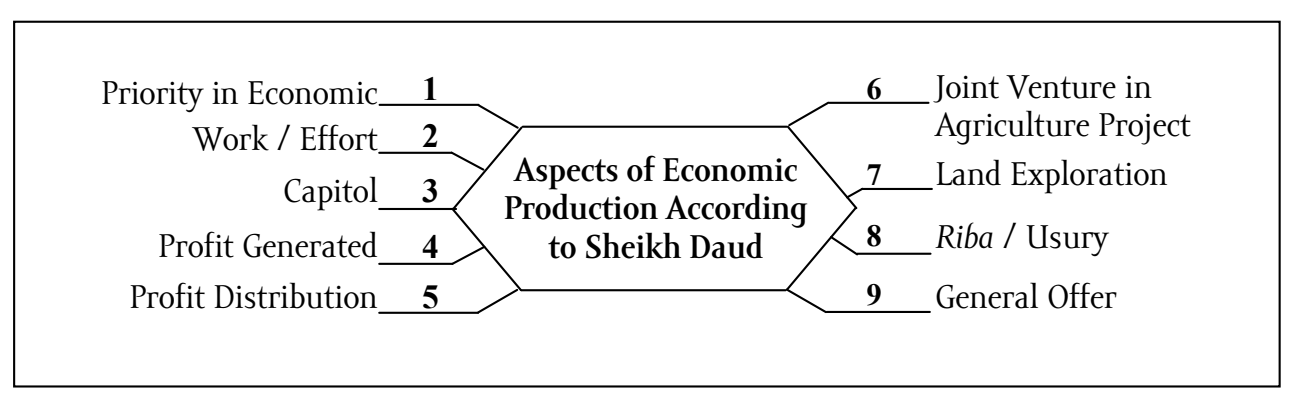

Aspects of production above show that the earlier Malay scholars have thought the progressive and dynamic development in line with the times. Certainly a valuable contribution and heritage of his works are complete, which has long existed since the mid-19 century not wasted. Even his writing about these particular aspects of production and book Furu' al-Masa'il general is

${ }^{28}$ Daud bin Abdullah al-Fatani, op. cit., p. 11. Also see: Joni Tamkin Borhan. 2002. Beberapa Aspek Pemikiran Syeikh Daud bin 'Abdullah Al-Fatani Dalam Perbankan Islam: Tumpuan Kepada Furu’ al-Masa'il. Jurnal AFKAR, V. 9, May-June, p. 208. 
still relevant and practical and can be a strong foundation in meeting the proceedings of every level of human need, regardless of place of past, present and future.

\section{REFERENCE}

Abdul Rahman Haji Abdullah. 1990. Pemikiran Umat Islam di Nusantara: Sejarah dan Perkembangannya Hingga Abad Ke-19. Kuala Lumpur: Dewan Bahasa dan Pustaka.

Azyumardi Azra. 1995. Jaringan Ulama Timur Tengah dan Kepulauan Nusantara Abad XVII dan XVIII: Melacak Akar-akar Pembaharuan Pemikiran Islam di Indonesia. Bandung, Indonesia: Penerbit Mizan.

Daud bin 'Abdullah al-Fatani, Furu' al-Masa'il, V. 2. Patani: Matba'ah Bin Halabi.

Hadenan bin Towpek. 2010. Beberapa Sumbangan Syeikh Daud al-Fatani Dalam Sistem Pengajian Pondok di Kelantan. Seminar Keintelektualan Islam, (The Centre for Islamic Thought and Understanding, UiTM Kelantan Branch, in collaboration with the Kelantan Federal Development Department, 31 May-1 June).

Hooker, M.B. (ed.). 1986. The Laws of South-east Asia (Vol. I: The-Modern Texts). Singapore: Butterworth \& Co (Asia) Pte Ltd.

Hooker, M.B. 1991. Undang-undang Islam di Asia Tenggara. Kuala Lumpur: Dewan Bahasa dan Pustaka.

Jomo K.S. \& Ishak Shari. 2003. Mikroekonomi. Kuala Lumpur: Utusan Publications \& Distributors.

Joni Tamkin Borhan. 2002. Beberapa Aspek Pemikiran Syeikh Daud bin 'Abdullah Al-Fatani Dalam Perbankan Islam: Tumpuan Kepada Furu' al-Masa'il. Jurnal AFKAR, V. 9, May-June.

Matheson, V. \& Hooker, M.B. 1988. Jawi Literature in Patani: the Maintenance of an Islamic Tradition. JMBRAS, Vol. 61, Part 1.

Mohamad @ Md. Som Sujimon \& Wan Sabri bin Wan Yusoff. 2003. Sheikh Da'ud al-Fatani's Contribution to Muslim Scholarship in Malaysia. Monograph on Selected Malay Intellectuals. Kuala Lumpur: Research Centre IIUM.

Wan Mohd. Shaghir Abdullah. 1990. Syeikh Daud bin Abdullah al-Fatani: Ulama dan Pengarang Terulung Asia Tenggara. Shah Alam: HIZBI.

Wan Mohd. Shaghir Abdullah. 1991a. Sejarah Rengkas Syeikh Daud bin Abdullah al-Fatani dan Karya-karyanya. Nadwah Ilmiah Tokoh Ulama Peringkat Kebangsaan Kali Keempat. (The Islamic Affairs Division, Prime 
Minister Department in collaboration with Islamic Academy of University of Malaya Kuala Lumpur, 17-19 Dicember).

Wan Mohd. Shaghir Abdullah. 1995. Manuskrip Islam Dunia Melayu Ditinjau Dari Pelbagai Peringkat. Intellectual Forum. (The Department of Malay Studies, University of Malaya).

Wan Mohd. Shaghir Abdullah. 2003. Mun-yatul Mushalli Syeikh Daud alFathani: Pengetahuan Sembahyang Masyhur. Kuala Lumpur: Khazanah Fathaniyah. 